\title{
The effect of material properties and isolation system on thermal bridge behavior
}

\section{Malzeme özelliklerinin ve yalıtım sisteminin isi köprüsü davranıșına etkisinin incelenmesi}

\author{
Güler GAYGUSUZOĞLU', Adem BAKIŞ 2* \\ ${ }^{1}$ Civil Engineering Department, Corlu Engineering Faculty, Namik Kemal University, Tekirdag, Turkey. \\ ggaygusuzoglu@nku.edu.tr \\ ${ }^{2}$ Ministry of National Defense, Sivas Construction of Real Estate Presidency, Sivas, Turkey. \\ adembakis1983@gmail.com
}

Received/Geliş Tarihi: 15.05.2016, Accepted/Kabul Tarihi: 08.11.2016

* Corresponding author/Yazıșllan Yazar

doi: $10.5505 /$ pajes.2016.53496

Research Article/Arastırma Makalesi

Abstract

Reducing the energy consumption is very important for the development of the countries. For this reason, energy consumption at the buildings is very important. It is necessary to know behaviours of thermal bridges, affects at insulation system utilized and materials constituting the thermal bridges very well to cut down thermal loss in buildings, this study searches affects at change in the thermal conductivity coefficients of concrete, wall and insulation materials used in the terrace floors on the thermal bridges. For this reason, apart from literature, examination on 9 insulation sections most frequently used for the terrace floors at reinforced concrete buildings in Turkey were realized. What is the effect of changes at insulation system and/or the concrete and the wall materials on the thermal bridge?". Answers to this question was researched. Calculations were made for temperature and heat flux distributions at wall-floor-beam combinations at different insulation states considering plastered state for first degree day area, as mentioned in TS825 Standard. For the calculations, QuickField 5.6 program, which gives realistic values and utilizes finite elements method was used. With the results of this study, it was seen how the behavior of the variance of the concrete, wall and insulation heat conductivity values at the thermal bridges changes in a two-dimensional way. As a result of the calculations, the biggest heat loss was obtained when thermal conductivity coefficient of the concrete increased. Besides, answers are given to questions such as which is the most productive section used in terrace floors?

Keywords: Thermal bridges, Thermal conductivity, Thermal loss, Terrace floors
Öz

Enerji tüketiminin azaltılması ülkelerin gelisimi içn cok önemlidir. Yapılarda enerji tüketimi bu nedenle büyük önem arz etmektedir. Binalarda ıSı kaybını azaltmak için ısı köprülerini, ısı köprülerini olușturan yalıtım sisteminin etkilerini ve kullanılan malzemenin davranıșlarını çok iyi bilmek gerekmektedir. Bu çalıșma, teras katlarda beton, duvar ve yalıtım malzemelerinin isıl iletkenlik katsayılarının değişiminin ısı köprüsüne etkilerini incelenmektedir. Bunun için literatürden farkl olarak Türkiye'de betonarme binaların teras katları için en sık kullanılan 9 kesit üzerinde inceleme gerçeklestirilmistir. "Yalitım sistemi, beton ve/veya duvar malzemesinin değişiminin Isı köprüsüne etkisi ne olmaktadır?" sorusuna yanit aranmistır. Hesaplamalar TS 825'te belirtilen birinci derece gün bölgesi için sıvalı durum göz önünde bulundurularak yapılmış olup farklı yalıtım çeşitlerinde duvar-döşeme-kiriş birlesimlerinin ISI akıları ve sicaklıkları hesaplanmistır. Hesaplamalarda gerçeğe yakın değerler veren ve sonlu elemanlar metodunu kullanan, QuickField 5.6 programından yararlanılmıstır. Bu çalışmanın sonuçları ile ısı köprülerinde beton, duvar ve yalıtım malzemelerinin isıl iletkenlik değerlerinin değișiminin iki boyutlu olarak nasıl değiștiği görülmektedir. En büyük ısı kaybı, betonun Isıl iletkenlik katsayısının artması sonucunda elde edilmektedir. Ayrica elde edilen sonuclarla teras katlarda kullanılan yalıtım cesitlerinin hangisinin daha verimli olduğu sorularına da yanıt verilmektedir.

Anahtar kelimeler: Isı köprüsü, Isıl iletkenlik, Isıl kayıp, Teras katlar

\section{Introduction}

Areas in the buildings which have greater thermal permeability than the average permeability are known as thermal bridges. Importance of thermal bridges is the extra heat losses occurring in these areas. The reason for these losses is the using of materials having different thermal conductivities as building elements.Reinforced concrete elements having much area usage in Turkey comprise an effective thermal bridge.Another reason for the extra heat loss in the thermal bridge is two-dimensional heat conduction occurring under the effect of different temperatures in parallel to the section composed because of the different thermal conductivities in these areas.

If opened, thermal bridges originate in two different ways: First one is the thermal bridges arising from geometry of the building, and they originate when a wide surface on the outside corresponds to a single intersection line inside the corners of the buildings. Two-dimensional thermal permeability shall take place on the corners since thermal permeability will be realized from the internal surface for each point of the exterior surface in different directions. The second one is thermal bridges formed when materials with different thermal conductivity come side by side. Energy loss from the reinforced concrete elements for the exterior surface will be more since thermal permeability of reinforced concrete elements is much higher than the wall material in the intersection regions of reinforced concrete beams, floors and walls [1].

It is discussed that there are discrepancies between real value and values that are calculated in the calculation of heat loss in buildings [1]. Approaches expressing actual situation with 
sufficient accuracy should be used [2]. National and international studies on this subject indicate that heat losses caused by thermal bridges should be taken into consideration to perform the calculations correctly [3],[4].Currently, in all international standards to determine energy needs with the purpose of heating buildings, one-dimensional heat loss calculations are made [5]-[9]. However, on the thermal bridges, when the materials having different thermal conductivities are side by side concurrently, lateral losses occur and two-dimensional heat conduction in these areas is effectively available.

Today significant part of the international studies on heat loss in thermal bridges is about problems of heat conduction which is two and three dimensional, linear or non-linear, and dependent or independent of time. Solutions are offered for these problems by using various noncommercial computer programs in which finite differences/finite elements/finite volume methods are utilized [10]-[17]. In order to examine effect of thermal bridges on the energy consumption, Theodosiou and Papadopoulos have performed a study on the thermal insulation configurations utilized between representational double walls in Greek buildings [18]. They restricted their study to insulation systems between double walls. Evola et al. have established an efficient solution to reduce primary energy need for heating in Terrace floors in the ratio of $25 \%$ when thermal bridges are improved in their study, in which significance of thermal bridges are stated [19]. In their study, Berggren et al. have emphasized the increasing significance of thermal bridges in the calculation of transmission and heat transfer for improving energy performance of buildings [20]. Garay et al. have established that heat flow formed differences in the range of $10-20 \%$ between one dimensional and two dimensional heat transfers [21]. Larbi has examined thermal bridges with two dimensional regression models and on three samples [22]. Gao et al. [23] attempted to find a solution with the help of a computer program for a three-dimensional model of thermal bridges. Martin et al. have stated that effect of thermal bridges are disregarded in the calculations, and have realized investigations for two different types of thermal bridges under dynamic conditions by using different methods [24].

In Turkey, the Standard of TS 825 [5] is used as a standard in limiting the energy needs for the heating of buildings and describing the calculation method that must be used, and the linear thermal permeability $\mathrm{U} \ell$ is defined to account for thermal bridges. To calculate the U $\ell$ values, the method that is defined in EN ISO 10211-1 [8] and EN ISO 10211-2 [9] is preferred, but this methodology only considers $U \ell$ values only for the combination of column-wall in this standard.

How to calculate the $\mathrm{U} \ell$ values for the combination of walls and floors is not defined in the standard. The number of studies related to heat bridges in Turkey are so less. In the existing studies, developing a model matter in the field of thermal behaviour of the thermal bridges has not been examined.On the other hand,without distorting the simplicity and reliability of the one-dimensional heat conduction equations, a model is developed for the addition of the twodimensional heat conduction in the thermal bridges to onedimensional equations were studied in [2]. Comparison of international thermal analysis methods of thermal bridges were studied by Dilmac and Alamut [3]. Thermal behavior of thermal bridges in different insulation systems were examined by Dilmac et al. [4] and the comparison of the basic approaches used in the thermal bridges has been performed by Akgun and Dilmac [25]. However, in none of the studies mentioned above the matter regarding what are the effects of the concrete, wall and insulation materials individually on the thermal bridges that are forming the thermal bridges in terrace floors was not examined.

In this study the effects of the concrete, wall and insulation materials on thermal bridges were examined. As the resultant grade of two-dimensional heat conduction give different results in floor and terrace floor, they have to be examined separately.Furthermore,this study searched terrace floors too. In the conjunctions of the reinforced concrete beams and floor with walls on the dispersion of the temperature and heat flux, the properties of the wall material that are used with concrete and insulation materials were being effective. Within this study, behaviors of thermal bridges were examined at wallfloor-beam combinations formed in the terrace floors of the reinforced concrete buildings in Turkey. For this purpose, QuickField 5.6 program which utilizes finite elements method was used, and the calculations were made by taking into consideration the dispersion of the temperature and heat flux in the wall-floor-beam combinations, the first degree day region and plastered status in case of different insulation situations.

\section{Calculations}

Investigation of thermal bridge was conducted assuming it consists of three different region (Figure 1). Resultant qa, horizontal qx, vertical qy heat flux values occurring in every region were obtained by entering internal and external temperatures, material specifications and lengths in QuickField 5.6 program. For this operation, closed contours were drawn for each and every investigated region (top, middle and bottom) of thermal bridge. In beam and floor sections which forms thermal bridge, internal surface and external surface temperatures were calculated by drawing linear contours generated in these surfaces.

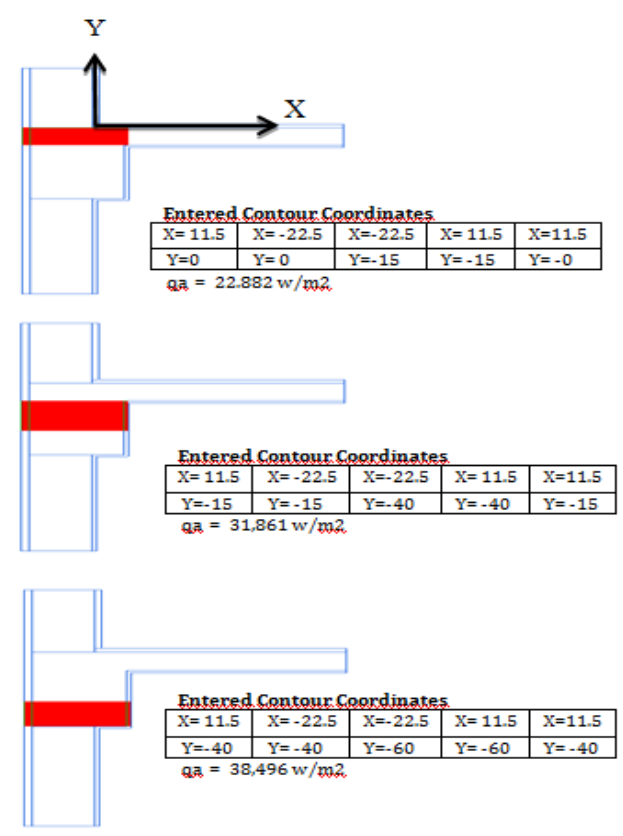

Figure 1: Non-insulated section and the resultant heat flux values obtained for every section $\left(\lambda_{\text {concrete }}=2.1 \mathrm{~W} / \mathrm{mK}\right.$, $\lambda_{\text {wall }}=0.45 \mathrm{~W} / \mathrm{mK}, \lambda_{\mathrm{ep}}=0.87 \mathrm{~W} / \mathrm{mk}, \lambda_{\mathrm{ip}}=0.87 \mathrm{~W} / \mathrm{mk}$ ). 
In Figure 1, how the contours were generated for noninsulated section and the resultant heat flux values obtained for every section are shown. For the non-insulated section in Figure1, calculated internal and external surface temperatures are, Tis $=15.5^{\circ} \mathrm{C}$, Tes $=9{ }^{\circ} \mathrm{C}$.

It is necessary to approach to total losses occurred in thermal bridge as of two dimensional. Together with lateral heat losses, value of existing heat losses might reach to nonignorable levels. In the formulation determined in Standard [5], it is calculated as below:

$$
U_{\ell}=b \cdot U_{T B}+\xi
$$

Here, $\mathrm{U}_{\ell}$ is the linear permeability of the thermal bridge, $\mathrm{U}_{\mathrm{TB}}$ is the permeability of the thermal bridge in the " $x$ " direction, " $b$ " is the width of the thermal bridge, and $\xi$ is of the thermal losses in the " $y$ " direction.

For calculation of $\mathrm{U}_{\mathrm{TB}}$, the formula below was used:

$$
U_{T B}=\frac{1}{\frac{1}{\alpha_{i}}+\sum \frac{d}{\lambda}+\frac{1}{\alpha_{e}}}
$$

Here $\alpha_{i}$ and $\alpha_{\mathrm{e}}$ are surface heat transfer coefficients internal and external respectively. $\lambda$ is thermal conductivity and $d$ is thickness. How much the thickness of floor slab will be taken is a problem during calculation of $\mathrm{U}_{\mathrm{TB}}$ in thermal bridges consisted of floor and beams. For simplicity of calculations, it was assumed that floor slab was cut at the thickness of beam. However, extra thermal losses which happen because of inward extension of floor slab had to been considered in $U_{T B}$ calculation. Therefore, in order to express the real thermal conduction, it is necessary for thermal resistance of the section reduced to beam thickness, to be reduced in the way that it balances extra thermal losses. Dilmac et. al. [2], in their study for floors, took qx values as below. Here, the same approach will be used for terrace floors:

$q_{x}=\frac{0.15 \times q_{\text {xupper }}+0.25 \times q_{\text {xmiddle }}+0.20 \times q_{\text {xlower }}}{0.60}$

Depth of the beam is $0.60 \mathrm{~m}$, height of the floor slab is $0.15 \mathrm{~m}$, height of the middle region is $0.25 \mathrm{~m}$ and height of the lower region is $0.20 \mathrm{~m}$ (Figure 1 ).

It is known that $\mathrm{q}_{\mathrm{x}}$ provides the below relation:

$$
q_{x}=\Lambda \times\left(T_{i s}-T_{e s}\right)
$$

In QuickField 5.6 software, internal surface and external surface temperatures ( $\mathrm{T}_{\mathrm{is}}, \mathrm{T}_{\mathrm{es}}$ ) for every section are obtained from the contours drawn for the same analysis. By substituting the results obtained from the package software program into equation (4), thermal transmittance $\Lambda$ that provides $\mathrm{q}_{\mathrm{x}}$ was calculated and in order to express that it was the obtained value from $\mathrm{q}_{\mathrm{x}}$ 's that were determined through two dimensional analysis, it was shown as $\left(\Lambda\left(\mathrm{q}_{\mathrm{x}}\right)\right)$. Based on this value, the thicknesses belonged to elements were determined in the way that they provided this transmittance, for non-insulated and insulated cases according to formulas of (5) and (6) below:

Non-insulated case:

$$
\left(\frac{1}{\Lambda_{q_{x}}}-\frac{d_{i p}}{\lambda_{i p}}-\frac{d_{e p}}{\lambda_{e p}}\right) \times \lambda_{\text {concrete }}=d_{\text {concrete }}
$$

Insulated case:

$$
\left(\frac{1}{\Lambda_{q_{x}}}-\frac{d_{c}}{\lambda_{c}}-\frac{d_{i p}}{\lambda_{i p}}-\frac{d_{e p}}{\lambda_{e p}}\right) \times \lambda_{\text {insulation }}=d_{\text {insulation }}
$$

Here $d_{c}, d_{i p}$ and $d_{e p}$ are thicknesses of concrete, internal plaster and external plaster respectively. $\lambda_{c}, \lambda_{i p}$ and $\lambda_{e p}$ are thermal conductivities of concrete, internal plaster and external plaster respectively.

The lateral heat loss is determined by summing the $q_{y}$ of each region

$$
q_{y}=q_{\text {yupper }}+q_{\text {ymiddle }}+q_{\text {ylower }}
$$

As noted above, $\xi$ may be interpreted as representing the heat transferred in the "y" direction through the area of width $\mathrm{d}_{\text {beam }}$ and length $1 \mathrm{~m}$. It must be in $\mathrm{W} /(\mathrm{m} \mathrm{K})$ units according to Eq. (1). In this case, $\xi$ can be calculated by using Eqs. (8)-(9).

$\mathrm{U}_{\mathrm{TB}}$ values show differences depending on material specifications and material thicknesses. On these differences, the effect of thermal transmittance changes of thermal bridge is at an important level.

When $\xi$ values are calculated according to the obtained values from QuickField 5.6 software, they are calculated depending on thermal bridge thickness, plaster thickness and, if insulating material exists, thickness of insulating material. $\xi$ values are obtained through multiplying total vertical heat flux with total thickness of thermal bridge, if exist, plaster and insulation thickness; then dividing the result to temperature difference between internal and external surfaces of thermal bridge.

Non-insulated case:

$$
\xi=\frac{\mathrm{q}_{\mathrm{y}} \times\left(\mathrm{d}_{\text {beam }}+\mathrm{d}_{\mathrm{ip}}+\mathrm{d}_{\mathrm{ep}}\right) \times 1}{\mathrm{~T}_{\mathrm{is}}-\mathrm{T}_{\mathrm{es}}}
$$

Insulated case:

$$
\xi=\frac{q_{y} \times\left(d_{\text {beam }}+d_{i n s}+d_{i p}+d_{e p}\right) \times 1}{T_{i s}-T_{e s}}
$$

Within this study, the behavior of the thermal bridge occurring in the terrace floors is evaluated in applications of different values of concrete, wall and insulation materials by selecting the sections (for different materials and thicknesses) used in the practical applications in our country. For this purpose, the temperature and heat flux distributions are calculated by using the QuickField 5.6 program for four climate zones given as Standard [5] of the thermal insulation rules in the buildings. Four different degree-day regions of Turkey according to Standard [5].

The interior temperature in the sections are selected as a constant $20^{\circ} \mathrm{C}$; for lower outside temperatures, the lowest temperature given in [5] is taken as $4{ }^{\circ} \mathrm{C}$ for first degree day area. As given in the standards, as the following parameters are used: $1 / \alpha_{i}=0.13 \mathrm{~m}^{2} \mathrm{~K} / \mathrm{W}$ and $1 / \alpha_{\mathrm{o}}=0.04 \mathrm{~m}^{2} \mathrm{~K} / \mathrm{W}$.

Comparisons are made by considering the exchange of the thermal conductivity of materials.

\subsection{Determination of the section and properties of changed materials}

In this study, the heat flux and temperature values occurring as a result of the changes made in the conductivity of thermal 
bridges are calculated on the nine main sections where different isolation conditions are applied in the terrace floors. They are non-isolated section (brick parapet), non-isolated section (concrete parapet), exterior insulated section, exterior insulated and insulated top terrace, interior insulated section, interior insulated and the top terrace insulated, insulation between double-wall, insulation between double-wall and top terrace insulated section, insulation between double-wall and top terrace and face of the beam insulated section (Figure 2).

\subsection{Determination of the section}

In the sections consisting of a reinforced concrete slab and a beam with outer wall, from the beam inner face, the length of covering is $70 \mathrm{~cm}$, from the beam bottom surface, the length of the wall is $80 \mathrm{~cm}$, from the beam top surface, the length of the wall is $50 \mathrm{~cm}$, the thickness of the beam, wall, and slab is 30 $\mathrm{cm}, 20 \mathrm{~cm}$, and $15 \mathrm{~cm}$, respectively, and the heights of both the total beam and covering are $60 \mathrm{~cm} \mathrm{[26].}$

Each section has a different thermal conductivity value. The values of three different thermal conductivities for concrete, wall, and insulation materials in the sections are taken as listed in Table 1.

The temperatures and heat flux values of nine main sections are shown in Figure 2. From Figure 2, significant differences were found to occur in temperature and heat flux values in terrace floors. In the non-isolated situation, the size of each heat flux arrow indicates the size of the heat loss. In particular, the application of insulation outside and on the terrace not only increases the indoor temperature and reduces the heat loss but also protects the structural elements, especially the reinforced concrete load bearing system elements, from thermal differences. Additionally, in this insulation situation, to obtain the best result, the parapet portion must use external insulation that wraps around the structure fully without cutting.

As seen from Figure 2, the prevailing heat flux is two dimensional. In different isolation situations, although the temperature and heat flux areas are drawn in the same scale, the increase or decrease in the length of the arrows denote the heat flux intensity and contraction or expansion between isotherms.

Table 1: The values of thermal conductivity of sections.

\begin{tabular}{ccc}
\hline$\lambda_{\text {insulation }}(\mathrm{W} / \mathrm{mK})$ & $\lambda_{\text {wall }}(\mathrm{W} / \mathrm{mK})$ & $\lambda_{\text {concrete }}(\mathrm{W} / \mathrm{mK})$ \\
\hline 0.03 & 0.15 & 1.2 \\
0.04 & 0.30 & 1.5 \\
0.05 & 0.45 & 2.1 \\
\hline
\end{tabular}

\section{Evaluation}

In the thermal bridges occurring in the beams and slabs, heat loss that occurred in the stages cannot be neglected in both the $\mathrm{x}$ and $\mathrm{y}$ directions. In this study, by changing the thermal conductivity of concrete, wall and insulation elements, the exchanges occurring in $\mathrm{U}_{\ell}, \mathrm{U}_{\mathrm{TB}}$ and $\xi$ values are examined. It can be observed that in the values of $U_{\mathrm{TB}}$ and $\xi$ calculated depending on increase in heat conduction values of the elements forming the thermal bridge exhibited a major increase.

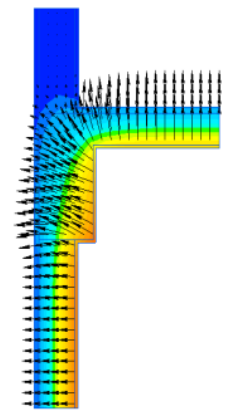

Non-isolated section(brick parapet)

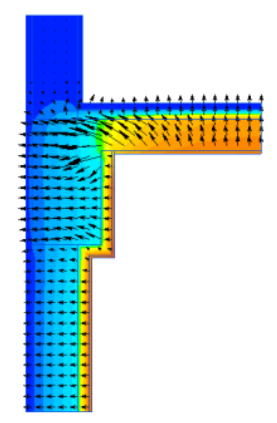

Interior insulated and the top terrace insulated

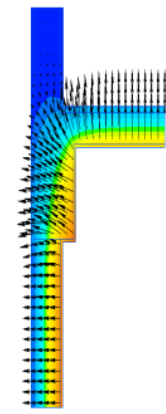

Non-isolated section(concrete parapet)

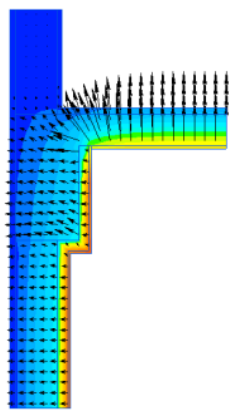

Interior insulated section

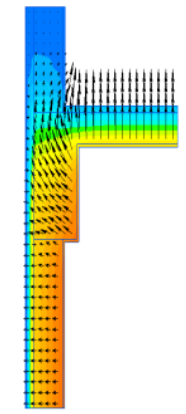

Exterior insulated section

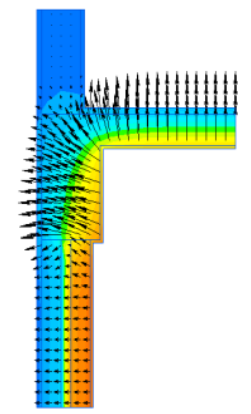

Insulation between double-wall
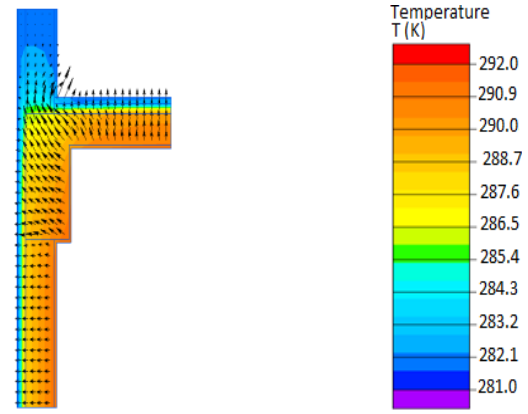

Exterior insulated section exterior insulated and insulated top terrace

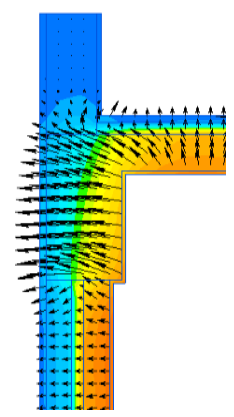

Insulation between double-wall and top terrace insulated section

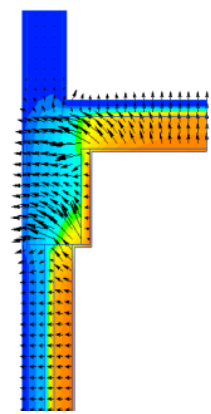

Insulation between doublewall and top terrace and face of the beam insulated section

Figure 2: The temperatures and heat flux values of nine main sections. 
The importance of the changes of $\xi$ at the location of the insulation and the heat conductivity at the thermal bridge changes is considerable. In the tables below (Table 2), the effects of the exchange of heat via the thermal conductivity of wall, concrete and insulation materials on the $U_{\mathrm{TB}}$ value are observed.

From Table 2 the exchange of thermal conductivity of concrete was found to cause significant heat losses. In the terrace floors, the value of $\mathrm{U}_{\text {тв }}$ applied between double wall insulation is observed to be close to the value of $\mathrm{U}_{\mathrm{TB}}$ of the non-isolated sections. When comparing the non-isolated situations and the between double-wall isolated situations, no further difference between these two isolations. It was observed that there was no effect of preventing heat loss in the application of insulation performed between double walls.

The external isolated section is the most productive section and also exhibits minimal losses in the $\mathrm{x}$ direction. With an increase in the exchange in the value of thermal conductivity of concrete, significant differences appeared in $\mathrm{U}_{\mathrm{TB}}$, and the increments have taken the lowest values in the exterior insulated section and exterior insulated and insulated top terrace section.

As presented Table 3, the exchange of the value of thermal conductivity of the wall made little difference in the exterior insulated section and exterior insulated and insulated top terrace section, the differences in the values of $\mathrm{U}_{\mathrm{Tв}}$ remained negligible. This situation indicates that the exchange in heat conductivity of a wall does not contribute to the thermal bridge in terms of heat losses in the $x$ direction in the structure.
Similarly, the effects of the exchanges of $\mathrm{U}_{\ell}$ in the thermal conductivity of concrete, wall and isolation materials and $\xi$ (lateral heat losses) were also examined.

Within the increase of value of thermal conductivity of a wall, considerable differences were observed in the value $U_{\ell}$. The value of thermal conductivity of concrete is the largest parameter affecting the thermal bridge. In the case of exchange of the thermal conductivity value of concrete, except the exterior insulated section and exterior insulated and insulated top terrace section, maximum differentiations were observed on the values $U_{\ell}$. As the value of thermal conductivity of concrete increases, the lateral heat losses are increasing, as well.

The values of $\xi$ for inclusion of lateral heat losses were different for the parapet brick and parapet concrete cases. It can be observed that the exchange of thermal conductivity of the wall did not elicit significant differentiations on the values $\mathrm{U}_{\ell}$. From Table 4, the insulation in the insulation between double-wall and insulation between double-wall and top terrace insulated section has no effect on the $\mathrm{U}_{\text {тв }}$ values of the exchanges of heat conductivity. This situation indicates that the double-wall insulation is equivalent to the non-isolated case.

In the thermal bridges that are consisting of beams and floors, heat losses are occurred both in the direction of " $x$ " and " $y$ " on the grades that cannot be neglected. With the results of this study, it is seen how the behaviors are changed in twodimensional forms that the change showed on the thermal bridges in the heat conduction values of the concrete, wall and insulation in terrace floors.

Table 2: The exchange of thermal conductivity of concrete material on the value of the $\mathrm{U}_{\mathrm{TB}}$.

\begin{tabular}{|c|c|c|c|c|}
\hline & \multirow{2}{*}{ Insulation Condition } & \multicolumn{3}{|c|}{$\left(\lambda_{\text {wall }}=0.30 \mathrm{~W} / \mathrm{mK}, \lambda_{\text {insulation }}=0.03 \mathrm{~W} / \mathrm{mK}\right.$ has been fixed $)$} \\
\hline & & $\lambda_{\text {concrete }}=1.2 \mathrm{~W} / \mathrm{mK}$ & $\lambda_{\text {concrete }}=1.5 \mathrm{~W} / \mathrm{mK}$ & $\lambda_{\text {concrete }}=2.1 \mathrm{~W} / \mathrm{mK}$ \\
\hline Sec1 & Non-isolated section (brick parapet) & 2.15 & 2.40 & 2.79 \\
\hline Sec2 & Non-isolated section (concrete parapet) & 2.15 & 2.40 & 2.79 \\
\hline Sec3 & Exterior insulated section & 0.57 & 0.60 & 0.70 \\
\hline Sec4 & Exterior insulated and insulated top terrace & 0.63 & 0.66 & 0.71 \\
\hline Sec5 & Interior insulated section & 0.94 & 1.06 & 1.25 \\
\hline Sec6 & Interior insulated and the top terrace insulated & 0.71 & 0.75 & 0.89 \\
\hline Sec7 & Insulation between double-wall & 2.14 & 2.40 & 2.78 \\
\hline Sec8 & $\begin{array}{l}\text { Insulation between double-wall and top terrace } \\
\text { insulated }\end{array}$ & 2.14 & 2.40 & 2.78 \\
\hline $\operatorname{Sec} 9$ & $\begin{array}{l}\text { Insulation between double-wall and top terrace and } \\
\text { face of the beam insulated section }\end{array}$ & 1.17 & 1.32 & 1.56 \\
\hline
\end{tabular}

Table 3: The variation thermal conductivity of wall material impact on the value UTB.

\begin{tabular}{|c|c|c|c|c|}
\hline & \multirow{2}{*}{ Insulation Condition } & \multicolumn{3}{|c|}{$\left(\lambda_{\text {concrete }}=2.1 \mathrm{~W} / \mathrm{mK}\right.$ ve $\lambda_{\text {insulation }}=0.03 \mathrm{~W} / \mathrm{mK}$ has been fixed) } \\
\hline & & $\lambda_{\text {wall }}=0.15 \mathrm{~W} / \mathrm{mK}$ & $\lambda_{\text {wall }}=0.30 \mathrm{~W} / \mathrm{mK}$ & $\lambda_{\text {wall }}=0.45 \mathrm{~W} / \mathrm{mK}$ \\
\hline Sec1 & Non-isolated section (brick parapet) & 2.79 & 2.79 & 2.79 \\
\hline Sec2 & Non-isolated section (concrete parapet) & 2.79 & 2.79 & 2.79 \\
\hline Sec3 & Exterior insulated section & 0.70 & 0.70 & 0.69 \\
\hline Sec4 & Exterior insulated and insulated top terrace & 0.64 & 0.71 & 0.75 \\
\hline Sec5 & Interior insulated section & 1.25 & 1.25 & 1.24 \\
\hline Sec6 & Interior insulated and the top terrace insulated & 0.89 & 0.89 & 0.90 \\
\hline Sec7 & Insulation between double-wall & 2.78 & 2.78 & 2.78 \\
\hline Sec8 & $\begin{array}{l}\text { Insulation between double-wall and top terrace } \\
\text { insulated }\end{array}$ & 2.78 & 2.78 & 2.78 \\
\hline Sec9 & $\begin{array}{l}\text { Insulation between double-wall and top terrace and face } \\
\text { of the beam insulated section }\end{array}$ & 1.56 & 1.56 & 1.56 \\
\hline
\end{tabular}


Table 4: The variation of the thermal conductivity of insulation material impact on the value UTB.

\begin{tabular}{|c|c|c|c|c|}
\hline \multirow{2}{*}{\multicolumn{2}{|c|}{ Insulation Condition }} & \multicolumn{3}{|c|}{$\left(\lambda_{\text {concrete }}=2.1 \mathrm{~W} / \mathrm{mK}, \lambda_{\text {wall }}=0.30 \mathrm{~W} / \mathrm{mK}\right.$ has been fixed $)$} \\
\hline & & $\lambda_{\text {insulation }}=0.03 \mathrm{~W} / \mathrm{mK}$ & $\lambda_{\text {insulation }}=0.04 \mathrm{~W} / \mathrm{mK}$ & $\lambda_{\text {insulation }}=0.05 \mathrm{~W} / \mathrm{mK}$ \\
\hline Sec1 & Non-isolated section (brick parapet) & 2.79 & 2.79 & 2.79 \\
\hline Sec2 & Non-isolated section (concrete parapet) & 2.79 & 2.79 & 2.79 \\
\hline Sec3 & Exterior insulated section & 0.70 & 0.75 & 0.80 \\
\hline Sec4 & Exterior insulated and insulated top terrace & 0.71 & 0.81 & 0.91 \\
\hline Sec5 & Interior insulated section & 1.25 & 1.31 & 1.35 \\
\hline Sec6 & Interior insulated and the top terrace insulated & 0.89 & 0.98 & 1.05 \\
\hline Sec7 & Insulation between double-wall & 2.78 & 2.78 & 2.78 \\
\hline Sec8 & $\begin{array}{l}\text { Insulation between double-wall and top terrace } \\
\text { insulated }\end{array}$ & 2.78 & 2.78 & 2.78 \\
\hline $\operatorname{Sec} 9$ & $\begin{array}{l}\text { Insulation between double-wall and top terrace and } \\
\text { face of the beam insulated section }\end{array}$ & 1.56 & 1.58 & 1.61 \\
\hline
\end{tabular}

\section{Conclusions}

The general results are given below:

- In the thermal bridges that are formed in the beam and floors, heat losses happen in the levels which cannot be neglected,

- In order to provide thermal comfort by less expenditure of energy in the buildings, the existing heat losses should be minimized. Accordingly, when calculating the heat losses occurred in the thermal bridges, the extra heat losses must be taken into consideration,

- When considering the effects of the change of the thermal conductivity of the wall on $\mathrm{U}_{\ell}$ it was seen that the least difference is from the exterior insulated section and exterior insulated and insulated top terrace section. These two observations have led us to the conclusion that insulation requires continuity,

- It was observed that there was no effect of preventing heat loss in the application of insulation performed in Turkey between double walls,

- It was seen that the maximum heat losses on the thermal bridges occurred by the change of the thermal conductivity of the concrete,

- The isolation of the thermal bridge and the choice of the materials are very important in terms of heat loss.

Designing of a building that is sustainable, economic and consuming minimum energy, requires the greatest parameter as calculating heat losses at thermal bridges. It is also taken into account that selecting materials and the most appropriate insulation systems to be applied for building systems would contribute to construction systems.

\section{References}

[1] Buyukakın MK, Oztuna S, Mihlayanlar E. "Thermal analysis of thermal bridges of concrete beams in buildings". International Scientific Conference UNITECH, Gabrovo, 21-22 November 2014.

[2] Dilmac S, Guner A, Senkal F, Kartal S. "Simple method for calculation of heat loss through floor/beam-wall intersections according to ISO 9164". Energy Conversetion and Management, 48(3), 826-835, 2007.

[3] Dilmac S, Alamut 0. "Comparison of international thermal analysis methods of thermal bridges". 1 ${ }^{\text {st }}$ International Exergy, Energy and Environment Symposium, Izmir, Turkey, 13-17 July 2003.
[4] Dilmac S, Can A, Kartal S. "The effect of climatic conditions and insulation systems on the thermal behavior of floors". Tesisat Mühendisliği Dergisi, 82, 49-65, 2004.

[5] TS 825 Turkish Thermal Insulation Standard "Thermal Insulation Requirements for Buildings", Ankara, Turkey, May, 2008.

[6] EN 832 "Thermal Performans of Building, Calculation of Energy Use for Heating". Residential Buildings-2000, European Committee for Standardization, Brussels, 2000.

[7] ISO 9164 "Thermal Insulation-Calculation of space Heating Requirements for Residential Buildings". International Organization for Standards, Geneva, 1989.

[8] TS EN ISO 10221-1 "Thermal Bridges in Building Constructions - Heat flows and surface temperatures" Part1: General calculation methods, Turkish Standards Institute, Ankara, 2000.

[9] TS EN ISO 10211-2 "Thermal Bridges in Buildings Constructions-Heat flows and surface temperatures" Part2: Linear Thermal Bridges, Turkish Standards Institute, Ankara, 2000.

[10] Mao G, Johonnesson G. "Dynamic calculation of thermal bridges". Energy and Buildings, 26(3), 233-240, 1997.

[11] Salgon JJ, Neveu A. "Application of modal analysis to modelling of thermal bridges in buildings". Energy and Buildings, 10(2), 109-120, 1987.

[12] Hassid S. "Thermal bridges across multilayer walls: An integral approach". Building and Environment, 25(2), 143-150, 1990.

[13] Hassid S. "Thermal bridges in homogeneous walls: A simplified approach". Building and Environment, 24(3), 259-264, 1989.

[14] Kosny J, Christian JE. "Thermal evaluation of several configuration of insulation and structural materials for some metal stud walls". Energy and Buildings, 22(2), 157-163, 1995.

[15] Clark MR, McCann DM, Forde MC. "Application of infrared thermography to nondestructive testing of concrete and masonry bridges". NDT \& E International, 36(4), 265-275, 2003.

[16] Kośny J, Kossecka E."Multi-dimensional heat transfer through complex building envelope assemblies in hourly energy simulation programs". Energy and Buildings, 34(5), 445-454, 2002.

[17] Larbi BA. "Statical modeling of heat transfer for thermal bridges of buildigs". Energy and Buildings, 37(9), 945-951, 2005. 
[18] Theodosiou TG, Papadopoulos AM. "The impact of thermal bridges on the energy demand of buildings with double brick wall constructions". Energy and Buildings, 40(11), 2083-2089, 2008.

[19] Evola G, Margani G, Marletta L. "Energy and cost evaluation of thermal bridge correction in Mediterranean climate". Energy and Buildings, 43(9), 2385-2393, 2011.

[20] Berggren B, Wall M. "Calculation of thermal bridges in (Nordic) building envelopes-risk of performance failure due to inconsistent use of methodology". Energy and Buildings, 65, 331-339, 2013.

[21] Garay R, Uriarte A, Inés A. "Performance assessment of thermal bridge elements into a full scale experimental study of a building façade". Energy and Buildings, 85, 579-591, 2014.

[22] Larbi BA. "Statical modeling of heat transfer for thermal bridges of buildigs". Energy and Buildings, 37(9), 945-951, 2005.
[23] Gao Y, Roux JJ, Zhao LH, Jiang Y. "Dynamic building simulation: a low order model for thermal bridges losses". Energy and Buildings, 40(12), 2236-2240, 2008.

[24] Martin K, Erkoreka A, Flores I, Odriozola M, Sala JM. "Problems in the calculation of thermal bridges in dynamic conditions". Energy and Buildings, 43(2), 529-538, 2011.

[25] Akgün G, Dilmac S. "Comparison of mathematical models used in thermal bridge problems". Istanbul Technical University Journal/d, 4(5), 3-16, 2005.

[26] Bakış A, Effects of Thermal Conductivity Changes to the Thermal Bridge Behavior in Concrete, Walls and Insulation Materials at Terrace Floors. Master's Thesis, Namık Kemal University, Tekirdag, Turkey, 2011. 